\title{
New Approach to Soil Formation in the Transitional Landscape Zone: Weathering and Alteration of Parent Rocks
}

\author{
Nur Ainun Pulungan ${ }^{1}$ \\ Junun Sartohadi ${ }^{2}$ (iD \\ 'Institute of Geography, Faculty of Geo- and Atmospheric Sciences, University of Innsbruck, Innsbruck, Austria; \\ Faculty of Agriculture, Gadjah Mada University, Togyakarta, Indonesia \\ Email:murainun.pulungan@ugm.ac.id Tel:+6287738719287 \\ ${ }^{2}$ Faculty of Agriculture, Gadjah Mada University, Yogyakarta, Indonesia \\ Email:junun@ugm.ac.id Tel:+6287839730956
}

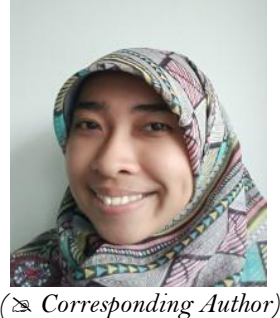

\begin{abstract}
Background and Objectives: Many studies have addressed the relation of soil formation and weathering. However, in the transitional landscape zone the soil formation is resulting not only from weathering process but also from alteration of parent rocks. The comparison of soil formation rates due to both processes is not studied yet. In Java, a transitional landscape zone is widely formed, and causes different types of soil formation in particular areas. The objective of this study was to compare the common concept of parent rock weathering with the concept of parent rock alteration in the soil formation. Materials and Methods: Purposive soil sampling was applied to collect the soils derived from weathering process and alteration. Laboratory analyses were applied to assess physical and chemical properties of soils. XRPD and $\mathrm{XRF}$ analyses were also conducted for mineralogical analysis. Results: The results showed that soil on weathered materials had brownish to grayish color, less than $30 \%$ of clay, $20-70 \mathrm{meq} / 100 \mathrm{gr}$ of CEC, $1.8-$ $4.3 \%$ of organic matter, medium to high cation bases and base saturation. While soils on altered materials showed reddish to orange color, contained more than $60 \%$ of clay, $<10 \mathrm{meq} / 100 \mathrm{gr}$ of CEC, $1.4-2 \%$ of organic matter, and very low cation bases and base saturation. Difference of mineral properties of soil developed on weathered- and altered materialswas shown by the presence of hematite. XRF results showed that weathered materials contained by $\mathrm{SiO}_{2}>\mathrm{Fe}_{2} \mathrm{O}_{3}>\mathrm{Al}_{2} \mathrm{O}_{3}$, however, altered materials contained by $\mathrm{SiO}_{2}>$ $\mathrm{Al}_{2} \mathrm{O}_{3}>\mathrm{Fe}_{2} \mathrm{O}_{3}$. Conclusion: It was concluded that in the transitional landscape zone, the soil formation was not always started by parent rock weathering. Weathering process resulted in top down process of soil formation. Alteration resulted in two processes of soil formation (bottom-up and top-down).
\end{abstract}

Keywords: Soil formation, Weathering, Alteration, Transitional zone, Landscape

Citation | Nur Ainun Pulungan; Junun Sartohadi (2018). New Approach to Soil Formation in the Transitional Landscape Zone Weathering and Alteration of Parent Rocks. Journal of Environments, 5(1): 1-7

History:

Received: 12 February 2018

Revised: 26 February 2018

Accepted: 2 March 2018

Published: 8 March 2018

Licensed: This work is licensed under a Creative Commons

Attribution 3.0 License (cc)

Publisher:Asian Online Journal Publishing Group
Contribution/Acknowledgement: The authors would like to thank Professor Hans Stoetter and Assoc.Professor Clemens Geitner from University of Innsbruck, Austria, for their valuable discussion during the research. We also thank to our colleagues in Bogowonto Research Team in Department of Environmental Geography, Universitas Gadjah Mada, Indonesia for their help in conducting field observation.

Funding: The authors are very grateful to OeAD for research funding.

Competing Interests: The authors declare that they have no conflict of interests.

Transparency:The authors confirm that the manuscript is an honest, accurate, and transparent account of the study was reported; that no vital features of the study have been omitted; and that any discrepancies from the study as planned have been explained.

Ethical: This study follows all ethical practices during writing.

\section{Contents}

1. Introduction

2. Study Area

3. Methods

4. Results

5. Discussion

6. Conclusions

References. 


\section{Introduction}

In a common concept of soil study, the soil formation is always started by weathering of parent rocks. Several studies have addressed the relation of soil formation and weathering [e.g. (Dubroeucq et al., 1998; Scarciglia et al., 2005; Webb and Girty, 2016)]. During soil formation, weathering of parent rock may generate mineral weathering, and thus the chemical process of weathering will transform primary minerals of the rocks into secondary minerals that may be formed in a pedogenic environment (Su et al., 2015). Furthermore, weathering of parent rocks generates the formation of $\mathrm{Si}$ and $\mathrm{Al}$ in the soil parent materials which determine the formation of noncrystalline components and crystallized clay minerals (Ugolini and Dahlgren, 2002).

A specific occurrence is found that soil formation can be also occurred due to alteration of parent rocks. This occurrence is particularly strong in the transitional landscape of Tertiary volcanic and Quaternary volcanic zones, where many areas are intruded by magma.The intrusive magma leads to parent rock alteration due to its heat released which induces the formation of particular minerals in the rocks(Carlson et al., 2009).As most of intrusive magma in Java was having a contact with groundwater (Pancake, 1949)the study area was mainly affected by a hydrothermal alteration, where water in the hydrothermal alteration caused changes in mineral composition of rocks as a result of interaction between fluida of hydrothermal and wall-rocks (Febriyana et al., 2014). However, the degree of alteration during soil formation is depended on the lithological characteristics of parent rocks (Bove et al., 2007).

These intrusive areas are widely formed in southern and middle parts of Java Island. As a consequence, the altered parent rock is largely found within this area especially where it is formed by Tertiary volcanic system. The center- and lower parts of Bogowonto catchment are widely affected by magmatic intrusion. Consequently, the soil formation in this area is strongly controlled by parent rocks alteration due to hydrothermal effect in the subsurface.

Only limited information is available on the comparison of weathering material and altered materials in soil formation. The aim of this study is to reveal the properties and characteristics of weathering of parent rocks and alteration of parent rocks. Weathering and alteration are two different significant processes that should be considered in soil formation in the study area.As there are wider areas in Java that have been intruded by the hydrothermal alteration, this study seems providing an important contribution to enrich the approach in soil formation studies.

\section{Study Area}

The study area, central part of Bogowonto Catchment, is located in the southern part of Java Island covering $329.11 \mathrm{~km}^{2}$ (see Fig. 1). It is laid on $7^{\circ} 17^{\prime} \mathrm{OO}{ }^{\prime} \mathrm{S}-8^{\circ} 47^{\prime} \mathrm{OO}{ }^{\prime} \mathrm{S}$ and $109^{\circ} 34^{\prime} 30^{\prime \prime} \mathrm{E}-110^{\circ} 09^{\prime} 00^{\prime} \mathrm{E}$. Its elevation ranges from 312.5 to $1100 \mathrm{~m}$ above sea level. From an administrative point of view, the study area belongs to the Regencies of Purworejo, Wonosobo, and Magelang, of the Central Java Province, and the Regency of Kulonprogo of the Yogyakarta Special Province.

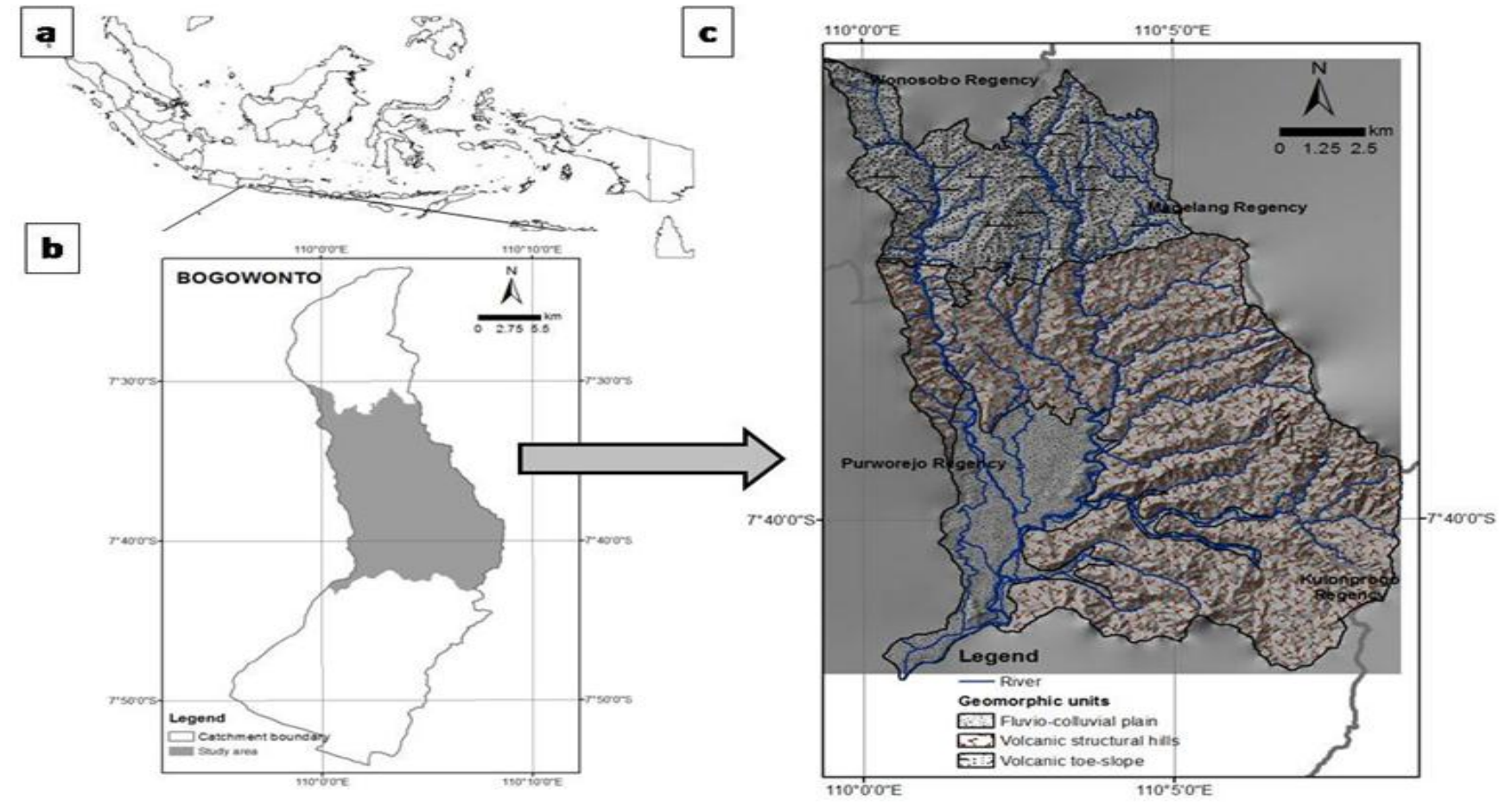

Source: ArcGIS analysis (2014)

Fig-1. Study area: (a) Indonesia; (b) Bogowonto Catchment; (c) Middle Bogowonto

The topography of the study area is characterised by gently to very steep slopes. This heterogeneity was resulted from geological and geomorphological setting which were made up by tectonic and volcanic activities in Tertiary to Quaternary periods. There are four geological formations in the study area, i.e. Old-Andesitic van Bemmelen Formation (andesitic breccias, lava andesite, tuff, lapili-tuff and agglomerate), Halang Formation (tuff, alternation of marl-sandstone, calcareous tufa), Andesitic intrusion and Alluvium. Today, some of these geological formations are covered by Quaternary volcanic deposits. The climatic setting of the study area is categorized by tropical monsoon conditions. The average annual rainfall varies between $2500 \mathrm{~mm}$ and $4000 \mathrm{~mm}$.

\section{Methods}

The soil samples were collected as disturbed samples. All samples were air dried within several days. Stones and roots were removed from the soil samples. Particle size analysis was conducted on $\Phi<2 \mathrm{~mm}$ of air-dried soils. 
The clay type analysis was conducted to obtain mineralogical properties. The pretreatment procedures for clay type analysis were similar to those used for particle-size distribution analysis. During the pretreatment, the soil samples were coupled with $400 \mathrm{~W}$ ultrasonic dispersion under $30-50 \mathrm{~Hz}$ for about 4 minutes. The ultrasonic dispersion was conducted to be strongly effective for dispersing soil particles. The clay fraction was assessed from the remained suspension of wet sieving in the sand separation process.

The gravity sedimentation was conducted during overnight sedimentation in order to separate clay from silt fraction. The remained suspension from sand separation process was diluted into 1L Atterberg sedimentation cylinder without any peptisator, and then mechanically shaken. The sedimentation was waited for certain interval following the principle of Stoke's Law (Kalra and Maynard, 1991) Afterwards, 25ml aliquot was taken by pipette and was oven-dried at $60^{\circ} \mathrm{C}$.

XRPD (X-Ray Powder Diffraction) was carried out for the next step of mineralogical analysis. Several gram of clay sample was prepared into preparat glass. The diffractogram was made of well oriented clay samples. The $\mathrm{Mg}-$ saturated samples were solvated by adding glycerol directly onto the moist clay, the $\mathrm{K}$-saturated samples were solvated by ethylene glycol, and then heated to $550^{\circ} \mathrm{C}$ respectively (Kalra and Maynard, 1991). The Bruker D-8 Advance was used as a XRPD scanner tool in this analysis.

$\mathrm{XRF}$ (X-Ray Fluorescence) was used to measure the quantitative mineral content in the soil parent materials. The $\mathrm{FeO}$ and total $\mathrm{Fe}$ contents were measured titrimetrically. And then, the $\mathrm{Fe}_{2} \mathrm{O}_{3}$ content was calculated from those results. $\mathrm{Si}$ and $\mathrm{Al}$ contents were determined using XRF after fusion in $\mathrm{Na}_{2} \mathrm{~B}_{4} \mathrm{O}_{7}$. The contents of the other elements in iron ore such as $\mathrm{Ti}, \mathrm{P}, \mathrm{Pb}, \mathrm{Mg}, \mathrm{Mn}, \mathrm{Zn}$, and $\mathrm{Cu}$ were determined using ICP-OES.

\section{Results}

\subsection{Comparison of Morphological, Physical, and Chemical Properties of Weathered-and Altered Materials}

Soil color and texture became the main parameters that clearly distinguished soils developed from altered and weathered materials. Soils developing from weathered materials showed brownish to grayish color whereas those developing from altered materials showed reddish to orange color (Table 1). Textures of soils developingfrom weathered materials had less than $30 \%$ of clay content while those developing from altered materials had much higher clay content, at most $>60 \%$.

Significant differencesin clay content related to CEC, cation bases, base saturated, and clay types of soils. Medium to high CEC of soils developing from weathered materials was followed by a greater amount of exchangeable cations and base saturated (see Table 1). Most of soils developing from weathered materials had medium CEC (10-40 me/100gr). It was usually found in soils developing from weathered sandstone, weathered andesitic breccias, and weathered volcanic ash deposit. Such CEC indicated that clay type of those materials is illite (Meuniers, 2005) and is usually found in young soils (Hardjowigeno, 2003). Soils developing from weathered tuff and weathered marl had highCEC that was> $50 \mathrm{me} / 100 \mathrm{gr}$. This high CEC indicated that clay type of those materials is montmorillonite.It is because montmorillonite has weak oxygen bonding that is easily substituted and causes excess negative charge, thus, results in high CEC (Meuniers, 2005).

Table-1. Comparison of weathered- and altered soils properties

\begin{tabular}{|c|c|c|}
\hline Comparative Parameters & Weathered materials & Altered materials \\
\hline Soil color & Hue: $7.5 \mathrm{YR}-10 \mathrm{YR}$ & Hue: $2.5 \mathrm{YR}-5 \mathrm{YR}$ \\
\hline Texture & Clay $\leq 30 \%$ & Clay $>60 \%$ \\
\hline CEC & $\begin{array}{l}\text { Medium - High } \\
(20-70 \mathrm{me} / 100 \mathrm{gr}) \\
\text { indicated clay type: illite- montmorillonite }\end{array}$ & $\begin{array}{l}\text { Very low } \\
(<10 \mathrm{me} / \operatorname{loogr}) \\
\text { indicated clay type: kaolinite }\end{array}$ \\
\hline $\begin{array}{l}\text { Cation bases } \\
(\mathrm{Ca}, \mathrm{Mg}, \mathrm{Na}, \mathrm{K})\end{array}$ & $\begin{array}{l}\text { Medium - High } \\
\text { (depended on soil parent materials type) }\end{array}$ & $\begin{array}{l}\text { Very low } \\
\text { (kaolinite has difficulties in cations } \\
\text { absorption) }\end{array}$ \\
\hline Base saturated & $\begin{array}{l}\text { Medium - High } \\
\text { (depended on the exchanging and holding } \\
\text { capacity of cations) }\end{array}$ & $\begin{array}{l}\text { Very low } \\
\text { (the exchanging capacity of cations is } \\
\text { very low) }\end{array}$ \\
\hline SOM & $1.8-4.3 \%$ & $1.4-2.0 \%$ \\
\hline $\mathrm{P}_{2} \mathrm{O}_{5}$ & $2-5 \mathrm{ppm}$ & $1-3 \mathrm{ppm}$ \\
\hline
\end{tabular}

In contrast, soils developing from altered materials hadvery low CEC ( $<10$ me/100gr), as shown in Table 1 . This low CEC indicated that clay type of those materials was kaolinite (Hardjowigeno, 2003) which is mainly formed due to intensive weathering or hydrothermal alteration of alumino-silicates (Pirajno, 2009). This low CEC was also followed by a fewer amount of exchangeable cations in altered materials. It was becausekaolinite is dominated by hydrolysis (Hardjowigeno, 2003) which causesreplacement of cation bases by ion $\mathrm{H}^{+}$. As the consequence, cation bases are released and lead to low base saturation in altered materials (see Table 1).

Differences between soils developing from weathered materials and soils developing from altered materials were also described by SOM and $\mathrm{P}_{2} \mathrm{O}_{5}$. However, the differences were not as significant as previous properties. Based on Table 1, soils developing from altered materials had lower content of SOM and $\mathrm{P}_{2} \mathrm{O}_{5}$ than those from weathered materials.

\subsection{Comparison of Mineralogical Properties of Weathered-and Altered Materials}

Mineral properties of soils developing from weathered- and altered materials were kaolinite, montmorillonite, cristobalite, boehmite, basanite, gypsum, and quartz (Fig.2 and Fig.3). According to XRPD analysis, montmorillonitewas often interstratified with illite. Therefore, the peak of illiteand montmorillonite often overlapped each other so that they could not be clearly distinguished. 
The presence of montmorillonite and kaolinite showed that clay transformation has been taking place in those soils. The frequently appearance of kaolinite in the graphic was the evidence of intensive weathering that transformed parent rocks into soil parent materials.

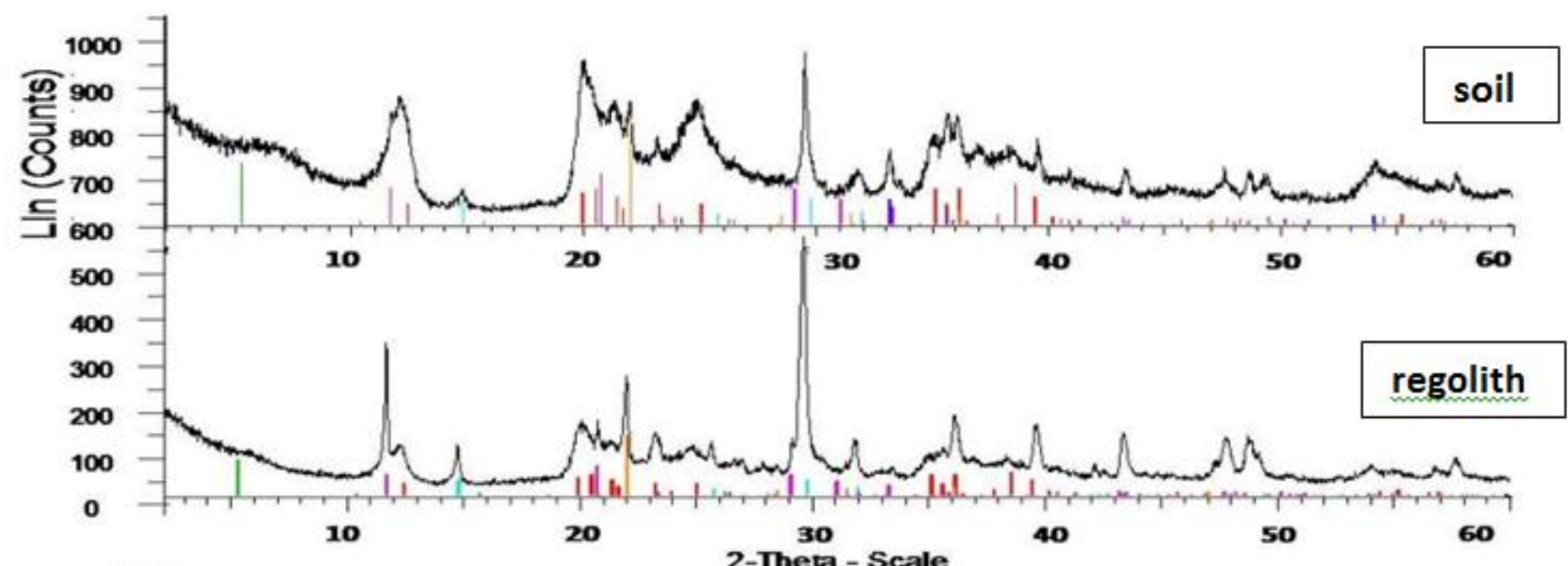

00-012-0447 (D) - Kaolinite 1T - A2SBO5(OH)4

00-060-0320 (I) - Montrnorillonite, glycolated, oriented - (Ca,Na)0.3A2/(Si, N $4010(\mathrm{OH}) 2-x \mathrm{H} 20$

04-007-2134 (") - Cristobalite; Cristobalite-alpha - SiO2

[.] 04-015-9580 (A) - hematile, syn - Fe2O3

00-014-0453 (D) - Bassanite, syn - CaSO40.5H2O

[. 04016-3025 (")-gypsum, syn - Ca(SO4)(H2O)2

Source: Laboratory analysis (2015)

Fig-2. XRPD result of altered materials (altered andesitic breccias)

a)

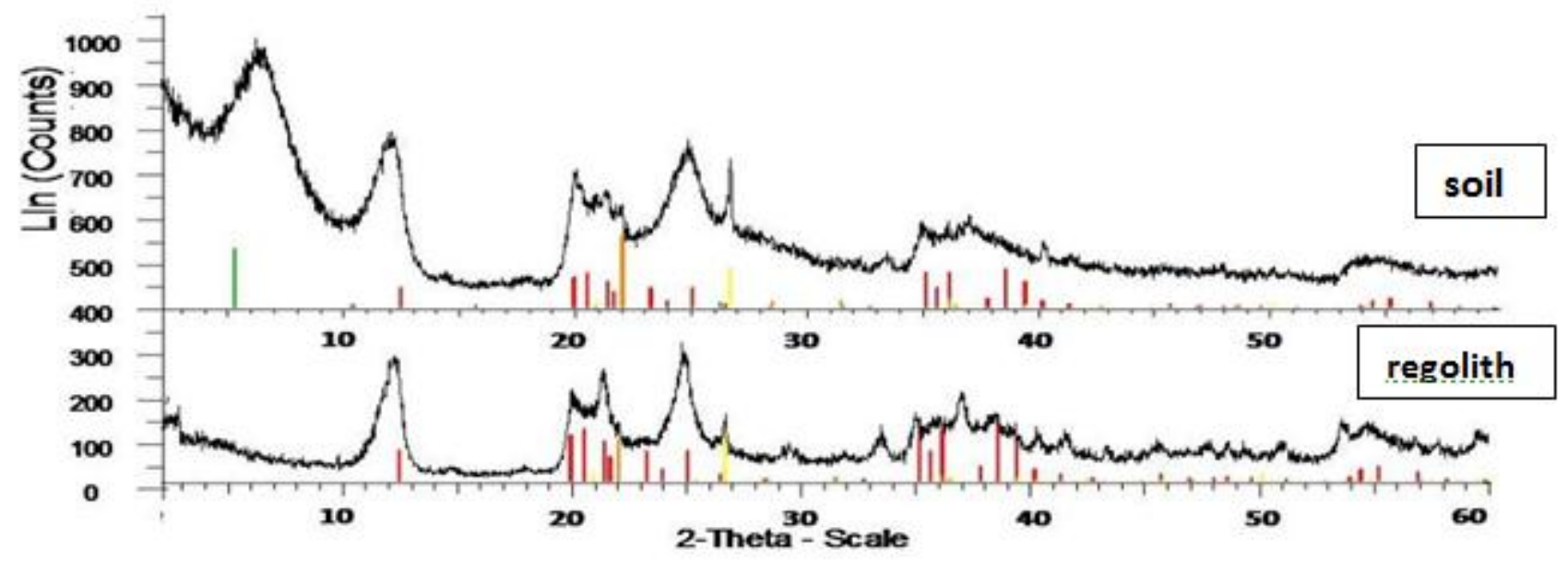

$1.100-012-0447$ (D) - Kaclinite 1T - A2Si2O5(OH)4

00-046-1045 (") - Quartz, syn - SiO2

1. $00-060-0320$ (I) - Montmorillonite, glycolated, oriented - (Ca,Na)0.3AD2(Si, N)4O1O(OH) 2 xH2O

04-007-2134 (') - Cristobalite; Cristobalite-alpha - SiO2

b)

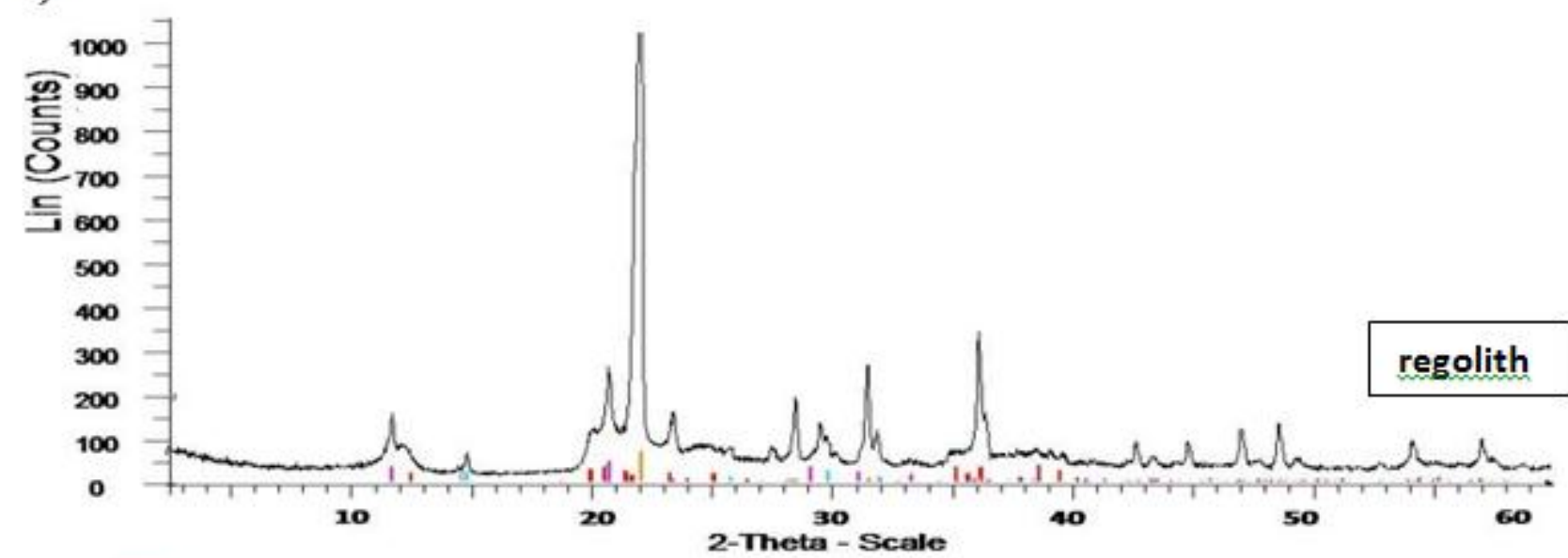

o-012-0447 (D) - Kaclinite 1T - N2SEOS(OH)4

04-07-2134 (*) - Cristobelite; Cristobedite-elpha - SiO2

04-010-5683 (1) - Bohmite - AO(OH)

O-014-0453 (D) - Bassanite, syn - CaSO4 - 5 H2O

O4-016-3025 (")-gypsum, syn-Ca(SO4)(H2O)2

Source: Laboratory analysis (2015)

Fig-3. XRPD result of weathered materials: a) sandstone, b) mar 
Other minerals like cristobalite, basanite, and gypsum proved that the soils were derived from volcanic materials. These minerals are typical minerals existed in a volcanic area (Sposito, 2008). Cristobalite belongs to silicates group $\left(\mathrm{SiO}_{2}\right)$ and is usually founded in a high temperature environment (Sposito, 2008) Gypsum and bassanite are parts of sulfates group so that their presence indicates Sulfur in the soil. Boehmite, as oxides and hydroxides mineral groups (Sposito, 2008) are typically found in the soils developed on intensive leaching process. Quartz, as the last weathered mineral, shows that weathering process does not reach the ultimate stageyet.

Table-2.The X-ray powder diffraction (XRPD) of parent rocks in the study area

\begin{tabular}{l|l}
\multicolumn{2}{c}{ Table-2.The X-ray powder diffraction (XRPD) of parent rocks in the study area } \\
\hline Parent rocks & Contents \\
\hline Andesite & Plagioclase, Illite/ montmorillonite, and probably a bit Pyroxene/hornblende \\
\hline Sandstone & Plagioclase, Illite/ montmorillonite, and Pyroxene/quartz \\
\hline Marl & Plagioclase, Illite/ montmorillonite, Quartz, Calcite and probably a bit Amphibole \\
\hline \multicolumn{2}{l}{ Source: Laboratory analysis (2015) }
\end{tabular}

The main difference of mineral properties of soils developingfrom weathered- and altered materialswas the presence of hematite (see Fig.2). Hematite is produced when K-feldspar (plagioclase-feldspar)is altered, usually during hydrothermal alteration. In fact, plagioclase was the main mineral in most of parent rocks in thestudy area (see Table 2). During plagioclase-feldspar alteration, there is Fe released from the lattice and oxidized to form hematite that produces reddish coloration (Kinnaird, 1985). The reddish color is an effect of less of oxygenduring oxidation process of altered material.

The XRF analysis showed that $\mathrm{SiO}_{2}$ was the dominant mineral in all soil samples (Table 3). The presence of $\mathrm{SiO}_{2}$ indicated that the parent rocks had been weathered and altered intensively. As a consequence, other major and minor minerals and alkali elements of the parent rocks had been leached (Sposito, 2008) and remaining Silicate (Si) and Aluminum (Al) as they were resistant minerals (Kinnaird, 1985).

Table-3. XRF analysis of minerals of weathered parent materials and of altered parent materials

\begin{tabular}{|c|c|c|c|c|c|c|c|c|c|}
\hline & \multicolumn{3}{|c|}{ Weathered volcanic ash materials } & \multicolumn{3}{|c|}{ Altered parent rock materials } & \multicolumn{3}{|c|}{ Weathered sandstone materials } \\
\hline \multirow{23}{*}{ 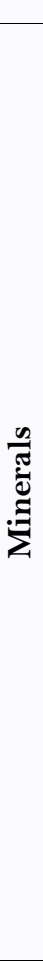 } & Formula & $\mathbf{Z}$ & Concentration (\%) & Formula & $\mathbf{Z}$ & Concentration (\%) & Formula & $\mathbf{Z}$ & Concentration (\%) \\
\hline & $\mathrm{SiO} 2$ & 14 & 37.89 & $\mathrm{SiO} 2$ & 14 & 45.10 & $\mathrm{SiO} 2$ & 14 & 41.32 \\
\hline & $\mathrm{Fe} 2 \mathrm{O} 3$ & 26 & 27.87 & $\mathrm{Al} 2 \mathrm{O} 3$ & 13 & 31.62 & $\mathrm{Fe} 2 \mathrm{O} 3$ & 26 & 28.32 \\
\hline & $\mathrm{Al} 2 \mathrm{O} 3$ & 13 & 27.69 & $\mathrm{Fe} 2 \mathrm{O} 3$ & 26 & 19.08 & $\mathrm{Al} 2 \mathrm{O} 3$ & 13 & 23.08 \\
\hline & $\mathrm{TiO} 2$ & 22 & 2.49 & $\mathrm{TiO} 2$ & 22 & 1.25 & $\mathrm{TiO} 2$ & 22 & 2.43 \\
\hline & P2O5 & 15 & 0.78 & $\mathrm{P} 2 \mathrm{O5}$ & 15 & 0.75 & $\mathrm{CaO}$ & 20 & 1.11 \\
\hline & $\mathrm{CaO}$ & 20 & 0.68 & SO3 & 16 & 0.47 & $\mathrm{~K} 2 \mathrm{O}$ & 19 & 0.96 \\
\hline & $\mathrm{MnO}$ & 25 & 0.62 & $\mathrm{Cl}$ & 17 & 0.41 & $\mathrm{P}_{205}$ & 15 & 0.79 \\
\hline & SO3 & 16 & 0.52 & $\mathrm{CaO}$ & 20 & 0.36 & $\mathrm{SO} 3$ & 16 & 0.53 \\
\hline & $\mathrm{Cl}$ & 17 & 0.43 & $\mathrm{~K} 2 \mathrm{O}$ & 19 & 0.32 & $\mathrm{Cl}$ & 17 & 0.47 \\
\hline & $\mathrm{K} 2 \mathrm{O}$ & 19 & 0.35 & $\mathrm{MnO}$ & 25 & 0.17 & $\mathrm{MnO}$ & 25 & 0.24 \\
\hline & $\mathrm{Nd} 2 \mathrm{O} 3$ & 60 & 0.17 & $\mathrm{Nd} 2 \mathrm{O} 3$ & 60 & 0.17 & $\mathrm{Nd} 2 \mathrm{O} 3$ & 60 & 0.23 \\
\hline & $\mathrm{SrO}$ & 38 & 0.12 & $\operatorname{Pr} 6 \mathrm{O} 11$ & 59 & 0.06 & $\operatorname{Pr} 6 \mathrm{O} 11$ & 59 & 0.10 \\
\hline & Pr6O11 & 59 & 0.10 & $\mathrm{ZrO} 2$ & 40 & 0.06 & $\mathrm{ZrO} 2$ & 40 & 0.08 \\
\hline & $\mathrm{ZrO} 2$ & 40 & 0.06 & $\mathrm{CuO}$ & 29 & 0.03 & $\mathrm{ZnO}$ & 30 & 0.07 \\
\hline & $\mathrm{ZnO}$ & 30 & 0.04 & $\mathrm{Cr} 2 \mathrm{O} 3$ & 24 & 0.02 & $\mathrm{CuO}$ & 29 & 0.05 \\
\hline & $\mathrm{CuO}$ & 29 & 0.04 & $\mathrm{SnO2}$ & 50 & 0.02 & & & \\
\hline & $\mathrm{Cr} 2 \mathrm{O} 3$ & 24 & 0.03 & $\mathrm{V2O5}$ & 23 & 0.02 & & & \\
\hline & $\mathrm{CeO} 2$ & 58 & 0.03 & $\mathrm{ZnO}$ & 30 & 0.02 & & & \\
\hline & $\mathrm{Ga} 2 \mathrm{O} 3$ & 31 & 0.02 & $\mathrm{Ga} 2 \mathrm{O} 3$ & 31 & 0.01 & & & \\
\hline & $\mathrm{SnO2}$ & 50 & 0.02 & $\mathrm{CoO}$ & 27 & 0.01 & & & \\
\hline & $\mathrm{Y} 2 \mathrm{O3}$ & 39 & 0.01 & & & & & & \\
\hline & $\mathrm{As} 2 \mathrm{O} 3$ & 33 & 0.01 & & & & & & \\
\hline \multirow{22}{*}{ 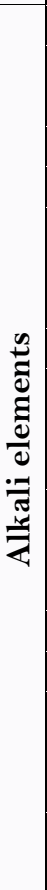 } & $\mathrm{O}$ & 8 & 43.85 & $\mathrm{O}$ & 8 & 46.13 & $\mathrm{O}$ & 8 & 43.80 \\
\hline & $\mathrm{Fe}$ & 26 & 19.49 & $\mathrm{Si}$ & 14 & 21.08 & $\mathrm{Fe}$ & 26 & 19.81 \\
\hline & $\mathrm{Si}$ & 14 & 17.71 & $\mathrm{Al}$ & 13 & 16.73 & $\mathrm{Si}$ & 14 & 19.32 \\
\hline & $\mathrm{Al}$ & 13 & 14.66 & $\mathrm{Fe}$ & 26 & 13.35 & $\mathrm{Al}$ & 13 & 12.21 \\
\hline & $\mathrm{Ti}$ & 22 & 1.49 & $\mathrm{Ti}$ & 22 & 0.75 & $\mathrm{Ti}$ & 22 & 1.46 \\
\hline & $\mathrm{Ca}$ & 20 & 0.48 & $\mathrm{Cl}$ & 17 & 0.41 & $\mathrm{~K}$ & 19 & 0.80 \\
\hline & $\mathrm{Mn}$ & 25 & 0.48 & $\mathrm{P}$ & 15 & 0.33 & $\mathrm{Ca}$ & 20 & 0.79 \\
\hline & $\mathrm{Cl}$ & 17 & 0.43 & $K$ & 19 & 0.27 & $\mathrm{Cl}$ & 17 & 0.47 \\
\hline & $\mathrm{P}$ & 15 & 0.34 & $\mathrm{Ca}$ & 20 & 0.26 & $\mathrm{P}$ & 15 & 0.35 \\
\hline & $\mathrm{K}$ & 19 & 0.29 & $\mathrm{~S}$ & 16 & 0.19 & $\mathrm{~S}$ & 16 & 0.21 \\
\hline & $\mathrm{S}$ & 16 & 0.21 & $\mathrm{Nd}$ & 60 & 0.15 & $\mathrm{Nd}$ & 60 & 0.20 \\
\hline & $\mathrm{Nd}$ & 60 & 0.15 & $\mathrm{Mn}$ & 25 & 0.14 & $\mathrm{Mn}$ & 25 & 0.19 \\
\hline & $\mathrm{Sr}$ & 38 & 0.10 & $\operatorname{Pr}$ & 59 & 0.05 & $\mathrm{Pr}$ & 59 & 0.09 \\
\hline & $\mathrm{Pr}$ & 59 & 0.09 & $\mathrm{Zr}$ & 40 & 0.04 & $\mathrm{Zr}$ & 40 & 0.06 \\
\hline & $\mathrm{Zr}$ & 40 & 0.04 & $\mathrm{Cu}$ & 29 & 0.02 & $\mathrm{Zn}$ & 30 & 0.05 \\
\hline & $\mathrm{Zn}$ & 30 & 0.04 & $\mathrm{Sn}$ & 50 & 0.02 & $\mathrm{Cu}$ & 29 & 0.04 \\
\hline & $\mathrm{Cu}$ & 29 & 0.03 & $\mathrm{Cr}$ & 24 & 0.02 & & & \\
\hline & $\mathrm{Ce}$ & 58 & 0.02 & $\mathrm{Zn}$ & 30 & 0.01 & & & \\
\hline & $\mathrm{Cr}$ & 24 & 0.02 & $\mathrm{Ga}$ & 31 & 0.01 & & & \\
\hline & $\mathrm{Sn}$ & 50 & 0.01 & & & & & & \\
\hline & $\mathrm{Ga}$ & 31 & 0.01 & & & & & & \\
\hline & $\mathrm{Y}$ & 39 & 0.01 & & & & & & \\
\hline
\end{tabular}

Source: Laboratory analysis (2015) 
Different percentage of minerals and alkali elements described different soil parent materials types. Major minerals contained in all soil sampleswere $\mathrm{SiO}_{2}, \mathrm{Fe}_{2} \mathrm{O}_{3}, \mathrm{Al}_{2} \mathrm{O}_{3}, \mathrm{TiO}_{2}, \mathrm{P}_{2} \mathrm{O}_{5}$. Major alkali elements contained in the soil sampleswere $\mathrm{O}, \mathrm{Fe}, \mathrm{Si}, \mathrm{Al}, \mathrm{Ti}$ (Table 3). However, the percentage of $\mathrm{SiO}_{2}, \mathrm{Fe}_{2} \mathrm{O}_{3}$, and $\mathrm{Al}_{2} \mathrm{O}_{3}$ could be used to distinguishprocesses occurred in the parent rocks. Weathered materials were mostly contained by $\mathrm{SiO}_{2}>$ $\mathrm{Fe}_{2} \mathrm{O}_{3}>\mathrm{Al}_{2} \mathrm{O}_{3}$ where the percentage of $\mathrm{SiO}_{2}$ ranged from $37.89 \%-41.32 \% ; \mathrm{Fe}_{2} \mathrm{O}_{3}$ ranged from $27.87 \%-28.32 \%$; $\mathrm{Al}_{2} \mathrm{O}_{3}$ ranged from 23.08\% - 27.69\% (Table 3). However, altered materials were consisted of $\mathrm{SiO}_{2}>\mathrm{Al}_{2} \mathrm{O}_{3}>\mathrm{Fe}_{2} \mathrm{O}_{3}$ where the percentage of $\mathrm{SiO}_{2}$ was $45.10 \% ; \mathrm{Al}_{2} \mathrm{O}_{3}$ was $31.62 \%, \mathrm{Fe}_{2} \mathrm{O}_{3}$ was $19.08 \%$ (Table 3). The dominance of $\mathrm{SiO}_{2}$ and $\mathrm{Al}_{2} \mathrm{O}_{3}$ in altered materials rather than in weathered materials showedthat mineral transforming process was more intensive in altered materials, and thus caused alkali elements leaching.

There were two common minerals formed in altered materials, i.e. Hematite and Magnetite. Hematite $\left(\mathrm{Fe}_{2} \mathrm{O}_{3}\right)$ and Magnetite $\left(\mathrm{Fe}_{3} \mathrm{O}_{4}\right)$ were iron oxides formeddue to contact-metasomatismprocess in igneous or metamorphic rocks (Pirajno, 2009). Hematite had lower iron (Fe) content than magnetite, which is $13.35 \%$ and $19.60 \%$ respectively (Table 4$)$.

Table-4. XRF analysis of altered parent rock materials

\begin{tabular}{|c|c|c|c|c|c|c|}
\hline & \multicolumn{3}{|l|}{ Hematite } & \multicolumn{3}{|c|}{ Magnetite } \\
\hline \multirow{21}{*}{ 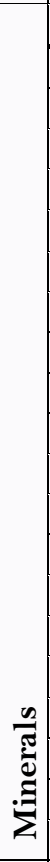 } & Formula & $\mathbf{Z}$ & Concentration & Formula & $\mathbf{Z}$ & Concentration \\
\hline & $\mathrm{SiO} 2$ & 14 & $45.10 \%$ & $\mathrm{SiO} 2$ & 14 & $29.53 \%$ \\
\hline & $\mathrm{Al} 2 \mathrm{O} 3$ & 13 & $31.62 \%$ & $\mathrm{Fe} 2 \mathrm{O} 3$ & 26 & $28.02 \%$ \\
\hline & $\mathrm{Fe} 2 \mathrm{O} 3$ & 26 & $19.08 \%$ & $\mathrm{Al} 2 \mathrm{O} 3$ & 13 & $22.81 \%$ \\
\hline & $\mathrm{TiO} 2$ & 22 & $1.25 \%$ & $\mathrm{Na2O}$ & 11 & $9.98 \%$ \\
\hline & $\mathrm{P} 205$ & 15 & $0.75 \%$ & $\mathrm{MgO}$ & 12 & $2.54 \%$ \\
\hline & $\mathrm{SO} 3$ & 16 & $0.47 \%$ & $\mathrm{TiO} 2$ & 22 & $1.91 \%$ \\
\hline & $\mathrm{Cl}$ & 17 & $0.41 \%$ & $\mathrm{CaO}$ & 20 & $1.11 \%$ \\
\hline & $\mathrm{CaO}$ & 20 & $0.36 \%$ & $\mathrm{P} 205$ & 15 & $0.82 \%$ \\
\hline & $\mathrm{K} 2 \mathrm{O}$ & 19 & $0.32 \%$ & $\mathrm{~K} 2 \mathrm{O}$ & 19 & $0.75 \%$ \\
\hline & $\mathrm{MnO}$ & 25 & $0.17 \%$ & $\mathrm{SO} 3$ & 16 & $0.70 \%$ \\
\hline & $\mathrm{Nd} 2 \mathrm{O} 3$ & 60 & $0.17 \%$ & $\mathrm{Cl}$ & 17 & $0.52 \%$ \\
\hline & Pr6O11 & 59 & $0.06 \%$ & $\mathrm{MnO}$ & 25 & $0.25 \%$ \\
\hline & $\mathrm{ZrO} 2$ & 40 & $0.06 \%$ & $\mathrm{La} 2 \mathrm{O} 3$ & 57 & $0.17 \%$ \\
\hline & $\mathrm{CuO}$ & 29 & $0.03 \%$ & $\mathrm{CeO} 2$ & 58 & $0.15 \%$ \\
\hline & $\mathrm{Cr} 2 \mathrm{O} 3$ & 24 & $0.02 \%$ & $\mathrm{Nd} 2 \mathrm{O} 3$ & 60 & $0.13 \%$ \\
\hline & $\mathrm{SnO2}$ & 50 & $0.02 \%$ & $\mathrm{ZrO} 2$ & 40 & $0.12 \%$ \\
\hline & $\mathrm{V2O5}$ & 23 & $0.02 \%$ & Pr6O11 & 59 & $0.07 \%$ \\
\hline & $\mathrm{ZnO}$ & 30 & $0.02 \%$ & V2O5 & 23 & $0.07 \%$ \\
\hline & $\mathrm{Ga} 2 \mathrm{O} 3$ & 31 & $0.01 \%$ & $\mathrm{CuO}$ & 29 & $0.05 \%$ \\
\hline & $\mathrm{CoO}$ & 27 & $0.01 \%$ & & & \\
\hline \multirow{19}{*}{ 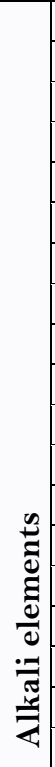 } & $\mathrm{O}$ & 8 & 46.13 & $\mathrm{O}$ & 8 & 40.83 \\
\hline & $\mathrm{Si}$ & 14 & 21.08 & $\mathrm{Fe}$ & 26 & 19.60 \\
\hline & $\mathrm{Al}$ & 13 & 16.73 & $\mathrm{Si}$ & 14 & 13.81 \\
\hline & $\mathrm{Fe}$ & 26 & 13.35 & $\mathrm{Al}$ & 13 & 12.07 \\
\hline & $\mathrm{Ti}$ & 22 & 0.75 & $\mathrm{Na}$ & 11 & 7.41 \\
\hline & $\mathrm{Cl}$ & 17 & 0.41 & $\mathrm{Mg}$ & 12 & 1.53 \\
\hline & $\mathrm{P}$ & 15 & 0.33 & $\mathrm{Ti}$ & 22 & 1.14 \\
\hline & K & 19 & 0.27 & $\mathrm{Ca}$ & 20 & 0.79 \\
\hline & $\mathrm{Ca}$ & 20 & 0.26 & $\mathrm{~K}$ & 19 & 0.62 \\
\hline & $\mathrm{S}$ & 16 & 0.19 & $\mathrm{Cl}$ & 17 & 0.52 \\
\hline & $\mathrm{Nd}$ & 60 & 0.15 & $\mathrm{P}$ & 15 & 0.36 \\
\hline & $\mathrm{Mn}$ & 25 & 0.14 & $\mathrm{~S}$ & 16 & 0.28 \\
\hline & $\mathrm{Pr}$ & 59 & 0.05 & $\mathrm{Mn}$ & 25 & 0.19 \\
\hline & $\mathrm{Zr}$ & 40 & 0.04 & $\mathrm{La}$ & 57 & 0.15 \\
\hline & $\mathrm{Cu}$ & 29 & 0.02 & $\mathrm{Ce}$ & 58 & 0.12 \\
\hline & $\mathrm{Sn}$ & 50 & 0.02 & $\mathrm{Nd}$ & 60 & 0.11 \\
\hline & $\mathrm{Cr}$ & 24 & 0.02 & $\mathrm{Zr}$ & 40 & 0.09 \\
\hline & $\mathrm{Zn}$ & 30 & 0.01 & $\mathrm{Pr}$ & 59 & 0.06 \\
\hline & $\mathrm{Ga}$ & 31 & 0.01 & $\mathrm{Cu}$ & 29 & 0.04 \\
\hline
\end{tabular}

Both hematite and magnetite were strongly depended onabundance of oxygen to produce higher or lower oxidation state (Pirajno, 2009). Hematite was formed under condition of Oxygen-rich than magnetite (Bove et al., 2007). Table 4 showed that hematite had $46.13 \%$ of Oxygen which was higher than Oxygen of magnetite that was $40.83 \%$.

Hematite was also formed when Silica had been released, as an indicator of alteration of parent rocks with correspondingly higher content of $\mathrm{SiO}_{2}$ and $\mathrm{Al}_{2} \mathrm{O}_{3}$ (see Table 4). In contrast, magnetite was a resistant mineralof which unaltered in the saprolite, and was indicated by lower content of $\mathrm{SiO}_{2}$ and $\mathrm{Al}_{2} \mathrm{O}_{3}$ (see Table 4).

\section{Discussion}

In the study area, soil formation is not always started by parent rock weathering.It is found that the soil parent materials were derived from weathered materials and altered materials (see Table 1). This was shown by higher content of $\mathrm{SiO}_{2}$ in altered materials than that in weathered materials (see Table 3). Its higher content of $\mathrm{SiO}_{2}$ indicated that alteration strongly influenced rock minerals changing during soil formation. However, among the weathered materials, weathered volcanic ash was more rapid of soil formation than weathered crystalline rock and 
sedimentary rock. The composition of parent volcanic ash i.e. non-welded glass particle and fine-sized particle and lack of layered minerals (Dahlgren et al., 1993) caused them susceptible to weathering.

Different types of soil parent materials resulted in different soil development in the study area. Commonly, the weathered materials formed A-C horizon because pedogenic process took longer time until it reached steady state development (Alexandrovskiy, 2007). Only in some areas having smooth relief performed Bw horizon as a result of intensive vertical water movement.

In intrusive areas, the soil development wasalso induced by alteration from the bottom of bedrock. It was usually initiated with bottom-up process of soil parent materials development. The bottom-up process meant that alteration become the agent for parent rock transformation into soil parent materials, instead of the weathering. As the result, the bottom-up process of alteration formed altered materials with very high content of clay(see Table 1) and formed several layer of B horizon along the profile (Pulungan, 2016). Most of altered materials were exposed to the surface of slopedue to landslides. Hereinafter, the altered materials were affected by weathering to formfurther soil parent material development. Under weathering process, altered materials weresupported by vertical water movement, as a form of usual top-down soil development.

Soils developed from altered materials showed specific characteristics as they were resulting from two processes (bottom-up and top-down) during profile development. The extreme clay content in altered materials (see Table 1)was possibly formed by feldspar kaolinitization (Sun, 2013) as the alteration replaces feldspar mineral in volcanic rocks into kaolinite minerals (Bove et al., 2007). (Zhang et al., 2007) also explained that intensive magmatic activities resulted in clay-altered materials due to mineralization of metallic sulfide depositsmainly found in volcanic materials (Taylor and Fryer, 1982).

\section{Conclusions}

It was concluded that in such transitional landscape zone, the soil formation can be controlled by both surface process (weathering) and subsurface process (alteration). Different types of soil parent materials resulted in different soil development in the study area.In comparison among theparent materials, altered materials showed more rapid of soil formation than weathered materials. Soils developing from weathered materials usually formed A-C horizon due to pedogenic process. Soils developed from altered materials showed specific characteristics and several layer of B horizon as they were resulting from two processes (bottom-up and top-down) during profile development.

\section{References}

Alexandrovskiy, A.L., 2007. Rates of soil-forming processes in three main models of pedogenesis. Mexican Journal of Geological Sciences, 24(2): 283-292. View at Google Scholar | View at Publisher

Bove, D.J., M.A. Mast, J.B. Dalton, W.G. Wright, D.B. Yager, S.E. Church, P. Von Guerard and S.E. Finger, 2007. Major styles of mineralization and hydrothermal alteration and related solid-and aqueous-phase geochemical signatures. US Geological Survey Professional Paper, 1651: 161-230. View at Google Scholar

Carlson, D.H., C.C. Plummer and L. Hammersley, 2009. Physical geology: Earth revealed. 9th Edn., New York: McGraw Hill.

Dahlgren, R., S. Shoji and M. Nanzyo, 1993. Mineralogical characteristics of volcanic Ash Soils. In S. Shoji, M. Nanzyo, \& R. Dahlgren (Eds.), Volcanic Ahs Soils: Genesis, properties and utilization, 21: 101-143. View at Google Scholar | View at Publisher

Dubroeucq, D., D. Geissert and P. Quantin, 1998. Weathering and soil forming processes under semi-arid conditions in two Mexican volcanic ash soils. Geoderma, 86(1-2): 99-122. View at Google Scholar | View at Publisher

Febriyana, D., Y. Aribowo and D.A. Widiarso, 2014. Geology and hydrothermal alteration of bantar rubber area and surrounding area, district of nanggung, Bogor regency, West Java Province. Geology Engineering e-Journal, 6(1): $218-232$.

Hardjowigeno, 2003. Ilmu Tanah. Bogor: IPB.

Kalra, Y.P. and D.G. Maynard, 1991. Methods manual for forest soil and plant analysis: Information Report NOR-X-319. Forestry Canada. Northwest Region. Northern Forestry Centre.

Kinnaird, J.A., 1985. Hydrothermal alteration and mineralisation of the alkaline anorogenic ring complexes of Nigeria. Journal of African Earth Sciences, 3(1-2): 229-252. View at Google Scholar $\mid$ View at Publisher

Meuniers, A., 2005. Clays. Germany: Springer.

Pancake, A.J., 1949. Outline or geomorphology or Java. Magazine of the Royal Dutch Geography. Company Full LXVI Part 3.

Pirajno, F., 2009. Hydrothermal processes and mineral systems. Geological Survey of Western Australia: Springer. pp: 73-164.

Pulungan, N.A., 2016. Spatial patterns of soil characteristics and soil formation in the transitional landscape zone, central part of Bogowonto Catchment, Java, Indonesia. Dissertation. Innsbruck University. Austria.

Scarciglia, F., E. Le Pera, G. Vecchio and S. Critelli, 2005. The interplay of geomorphologic processes and soil development in an upland environment, Calabria, South Italy. Geomorphology, 69(1-4): 169-190. View at Google Scholar $\mid$ View at Publisher

Sposito, G., 2008. The chemistry of soils. 2nd Edn., New York: Oxford University Press. pp: 17-27.

Su, N., S.Y. Yang, X.D. Wang, L. Bi and C.F. Yang, 2015 Magnetic parameters indicate the intensity of chemical weathering dev eloped on igneous rocks in China. Catena, 133: 328-341. View at Google Scholar | View at Publisher

Sun, Q., 2013. Rock alteration in a hydraulic engineering project in Southwest China. Arabian Journal of Geosciences, 8: 23-27. View at

Publisher
Taylor, R.P. and B.J. Fryer, 1982. Rare earth element geochemistry as an aid to interpreting hydrothermal ore deposits. In: Evans AM (Ed), Mineralisation associated with acid magmatism. New York: John Wiley \& Sons. pp: 357-365.

Ugolini, F.C. and R.A. Dahlgren, 2002. Soil development in volcanic ash. Global Environmental Research: 69-81. Retrieved from http://www.airies.or.jp/attach.php/6a6f75726e616c5f30362d32656e67/save/0/0/06_2-09.pdf.

Webb, H.N. and G.H. Girty, 2016. Residual regolith derived from the biotite-controlled weathering of cretaceous tonalite-quartz diorite, Peninsular ranges, Southern California, USA: A case study. Catena, 137: 459-482. View at Google Scholar | View at Publisher

Zhang, Y.S., Y.X. Qu and J.R. Liu, 2007. Engineering geological research on altered rocks in the area of NW Yunnan along Yunnan-Tibet Railway line. Chinese Journal of Geotechnical Engineering, 29(4): 531-536. View at Google Scholar 